IZA DP No. 8573

Migration of Graduates within a Sequential Decision Framework: Evidence from Poland

Mikotaj Herbst

Pawet Kaczmarczyk

Piotr Wójcik

October 2014 


\title{
Migration of Graduates within a Sequential Decision Framework: Evidence from Poland
}

\author{
Mikołaj Herbst \\ EUROREG, University of Warsaw
}

Paweł Kaczmarczyk

CMR, University of Warsaw

and IZA

\author{
Piotr Wójcik
}

University of Warsaw

\section{Discussion Paper No. 8573 \\ October 2014}

\author{
IZA \\ P.O. Box 7240 \\ 53072 Bonn \\ Germany \\ Phone: +49-228-3894-0 \\ Fax: +49-228-3894-180 \\ E-mail: iza@iza.org
}

Any opinions expressed here are those of the author(s) and not those of IZA. Research published in this series may include views on policy, but the institute itself takes no institutional policy positions. The IZA research network is committed to the IZA Guiding Principles of Research Integrity.

The Institute for the Study of Labor (IZA) in Bonn is a local and virtual international research center and a place of communication between science, politics and business. IZA is an independent nonprofit organization supported by Deutsche Post Foundation. The center is associated with the University of Bonn and offers a stimulating research environment through its international network, workshops and conferences, data service, project support, research visits and doctoral program. IZA engages in (i) original and internationally competitive research in all fields of labor economics, (ii) development of policy concepts, and (iii) dissemination of research results and concepts to the interested public.

IZA Discussion Papers often represent preliminary work and are circulated to encourage discussion. Citation of such a paper should account for its provisional character. A revised version may be available directly from the author. 
IZA Discussion Paper No. 8573

October 2014

\section{ABSTRACT}

\section{Migration of Graduates within a Sequential Decision Framework: Evidence from Poland}

According to the economic literature human capital is a critical growth factor. This is why migration of individuals well endowed with human capital is subject of interest for both academics and policymakers. The aim of this paper is to identify main drivers of highly skilled migration within Poland. Following the findings of earlier studies, we argue that the spatial mobility of individuals should not be considered in terms of one-time displacement, but rather as a sequence of migration decisions within certain time period. We assume that the propensity to migrate depends on factors to be interpreted in terms of aspirations and capabilities and, additionally, the importance of those factors can change during the education process and in the life course. Applying multinomial logit modelling on the unique database on Polish graduates we find that all tested migration strategies can be explained both in terms of capacities to aspire and capacities to realize, whereas repeat migration is driven particularly by characteristics related to level of aspirations and return migration - by low capacities to realize the migration projects.

JEL Classification: $\quad$ I25, J24, J61, J62

Keywords: $\quad$ high skilled migration, graduates, sequential decision framework, capacity to aspire, capacity to realize

Corresponding author:

Mikołaj Herbst

EUROREG, University of Warsaw

Krakowskie Przedmieście 26/28

00-927 Warsaw

Poland

E-mail: mherbst@uw.edu.pl 


\section{Migration of graduates within a sequential decision framework. Evidence from Poland ${ }^{1}$ \\ Mikołaj Herbst, Paweł Kaczmarczyk and Piotr Wójcik}

\section{Introduction}

The goal of this paper is to better understand the drivers of interregional migration of well educated individuals. Human capital is commonly considered as an important factor of economic growth. Therefore, the directions and scale of its mobility are likely to influence the future performance of regional economies, which makes skilled migration subject of interest of both academic researchers and policymakers.

We chose to investigate the issue of human capital mobility using data from Poland, which we consider a valuable case for such studies. Poland is relatively big, polycentric economy, with dynamically developing university network and growing demand for education. The transformation of the 1990s triggered a change from an elite to a mass tertiary education system. The net enrolment rate grew from $9.8 \%$ in the academic year 1990/1991 to $40.8 \% 20$ years later. The share of people aged 25-64 attaining tertiary education grew between 1997 and 2010 by $7.2 \%$ annually, doubling the average OECD rate of growth for this period. At the same time, the structure of the economy has changed very profoundly, causing the rise of unemployment. In sum, the transformation to a market economy created a pressure to attain a higher education, and to be mobile, in order to keep pace in the increasingly competitive conditions (Kwiek 2011).

Although the issue of student and graduate mobility between regions is widely studied in some countries with well developed statistical reporting on migrations, it is rather unexplored in the case if Poland. Polish statistical system does not provide any information on the migratory flows by educational attainment. Until now, there were also no survey data allowing this type of analysis. Few attempts to study the patterns of skilled migration between the Polish regions were based on original, user-generated data. Herbst (2010) exploited a unique dataset from a Polish social networking website to assess the ability of Polish academic cities to attract and absorb human capital. Herbst and Rok ( (2014)) eventually used the same data to develop a typology of skilled migration and to construct the empirical model of student and graduate migration. They found that the spatial mobility of human capital in Poland is low, and the distance between the home region and

\footnotetext{
${ }^{1}$ The research was carried under the project 'Human capital mobility and regional growth in Poland. Theory, empirical model and the implications for public policy', funded by the National Science Centre (NCN), UMO2011/01/B/HS4/04727.
} 
potential destination plays the most significant role in migration decisions. Migrations of skilled individuals act in favour of metropolitan areas, which experience a net gain of human capital, while all other regions are subject to brain drain.

Following the findings of earlier studies (see literature review in section 2), we argue that the spatial mobility of individuals should not be considered in terms of one-time displacement, but rather as a sequence of migration decisions within certain time period. Moreover we assume that the propensity to migrate depends on factors to be interpreted in terms of aspirations and capabilities and, additionally, structure and importance of those factors can change in the life course and along the education process. Therefore, in this article we develop the empirical model of sequential migration behaviour to test a series of hypotheses related to factors driving particular migration strategies (see section 3).

The remaining part of the article is organized as follows: Section 2 discusses the main theoretical and empirical findings on the drivers of graduate mobility. It also introduces the concept of sequential migration behaviour, as well as the concepts of capacity to aspire and capacity to realize, which are crucial for our approach. Section 3 explains the empirical strategy and describes data used for estimation. Section 4 presents the results of our study, and section 5 concludes.

\section{Drivers of graduate mobility - literature review}

According to theoretical and empirical economic literature human capital is a critical growth factor for review see Herbst and Rok (2013). Thus mobility of persons well endowed with human capital is extremely important for both sending and receiving regions / countries. In this article we assess the mobility patterns of Polish graduates. In this section we will conceptualise our approach and place the issue under consideration in the context of the scientific debate on migration and its causes. Importantly due to the fact that most of the theories do not distinguish explicitly between internal and international migration we refer to a set of theories which can be useful in answering research questions asked in this article.

Drivers of migration - understood in both international as well as internal terms - lie in the very centre of the theoretical and empirical migration discourse. Traditional economic literature on migration presents mobility as an outcome (by-product) of spatial differences in economic 
opportunities (Hicks 1932). Those economic opportunities are defined predominantly in terms of incomes or wages, less often in terms of well-being or standards of living.

Along these lines wages differentials are commonly considered as the most important factors responsible for human mobility. This is clearly present in the Hecksher-Ohlin-Samuelson framework arguing that mobile agents are responding to wage differentials being an outcome of spatial misdistribution of factors of production (Mundel 1957; Samuelson 1948). Harris and Todaro (1970) introduced the risk factor into the analysis by arguing that migration is a function of expected rather than absolute wage differentials (with unemployment rate as a proxy of employment probability). Considerations concerning risk, uncertainty and time preferences are manifestly present in the human capital approach as proposed by Sjaastad (1962). According to this approach migration can be assessed as an investment decision aimed to finding an optimal utilization of actual and potential human capital. As a typical neoclassical microeconomic approach it explains the migration decision in terms of rational analysis based on cost-benefit comparisons whereas the expected and discounted incomes in the origin and (potential) destination countries are compared. Importantly, Sjaastad and followers suggest considering not only purely monetary costs and benefits but also nonfinancial and psychological costs attached to migration. Moreover, the variables in question depend on the expectations and their formation as well as preferences regarding time and risk. Thus such factors as age, sex and education level are expected to play a critical role in setting of migration propensity. In this regard human capital approach is similar to the idea of immigration market as proposed by Borjas (1994) who linked the selectivity of migration to the rates of return to observable and non-observable characteristics and argued that immigrants tend to positively selected when the payoff for observed characteristics abroad is higher than in the country of origin (in case of negative selection the opposite holds).

It is important to note, however, that there is considerable debate regarding the units of analysis for proper migration decision studies. The approaches quoted above would argue for (purely) individualistic migration decision making (rational agents without social nor family context) - in simple words it would mean that individuals and only individuals make migration decisions (DaVanzo 1981). This kind of approach has been seriously challenged by a large number of scholars arguing that in most cases the family is a reasonable decision-making unit. Mincer (1978) claimed that migration studies should be conducted at the family level rather than because it is not an individual gain but family gain which matters for mobility decisions. Additionally he proposed a typology of movers who are clearly motivated by family related motives (tied stayers / tied movers). The neoclassical microeconomic approach to migration has been also seriously challenged by Stark (1984) 
and Stark and Bloom (1985) within the New Economics of Labour Migration (NELM). Stark and Bloom argue that families or even larger social units who are actively involved in migration decision making. If we acknowledge that it would imply as a next step that migration can be understood not only as a mobility driven by profit maximization but also as a risk diversification strategy (allocation of labour). Additionally NELM brings into the discussion the very issue of relative deprivation. It is based on a general observation saying that one's comparison of his/her income with the incomes of other members of particular reference group (to be determined) may result in a feeling of relative deprivation and thus become source of negative utility. The general prediction is that, holding all other variables constant, a non satisfactory or deteriorating relative position within a reference group will result in migration decision and that expected outcome of this decision is change in one's relative income position (decrease in relative deprivation). Another large strand of literature focuses on importance of social capital and migrant networks responsible for lowering the risks and costs associated with spatial mobility. According to Fawcett (1987) migrant networks serve as a channel of information, and normative structures, influence the selection of destinations and origin sites, determine, to a degree, who migrates from communities and households, shape the size and momentum of migration and in turn might change migration into a self-perpetuating process.

Generally there is a set of testable hypotheses to be derived from the theoretical literature on migration and its drivers. First, wages differentials are important factors explaining directions and intensity of flows (Hatton and Williamson 2002; Carletto et al. 2004; Quinn 2006). Second, not only absolute wages or incomes do matter - the feeling of being relatively deprived is also discussed as possible driver of migration (Stark and Taylor 1989, 1991a, 1991b; Queen 2006; Czaika 2011). Third, migration is highly selective. Selectivity of migration is conditional on such factors like human capital / education / skills (Kaczmarczyk 2005; Anacka 2010; Anacka and Okólski 2010; Grabowska and Okólski 2009; Mosca and Wright 2010; Venhorst, Van Dijk et al. 2010), age (Kaczmarczyk 2005; Kaczmarczyk and Okólski 2008; Gottlieb and Joseph 2006; Grabowska and Okólski 2009; Mosca and Wright 2010), gender (Faggian and McCann 2007; Faggian, McCann et al. 2006), marital status and family situation (Newbold 2001; Haapanen and Tervo 2011), migration experience (Kodrzycki 2001; Kaczmarczyk 2005), etc. Fourth, access to various forms of social capital is responsible for migration propensity on the individual level and determines to a large degree the pace of migration in social terms (migration as a social process) (Haapanen and Tervo 2011; Wulff 2008; Kaczmaczyk 2005). Fifth, structural context does matter. Empirical studies show that migration is to be assessed in terms of following effects: 1) purely economic factors (e.g. structure and conditions of the labour market (Gottlieb and Joseph 2006); 2) so-called new factors of migration, i.e. types of amenities (Delisle and 
Shearmur 2010); and particularly in case of graduates 3) specialization of a given region (Faggian et al. 2006; Gibbons and Vignoles 2012; Haapanen and Tervo 2011).

In this paper we refer not only to traditional literature on migration but also to the modelling of migration decision. As suggested by the Harris-Todaro model the foreign income can be weighted by the probability of being employed (Harris and Todaro 1970). Because in many cases this 'probability' is not easily identifiable (generally available unemployment rate may turn to be fuzzy measure) many search models would imply that migrants may tend to simply try their luck - in fact, there are certain destination characteristics that are only observable once the migrant arrives at destination (Molho 1986). On the other hand, migrants or would-be migrants may apply a 'wait and see' strategy and delay departure (migration or return migration) (Burda 1993). These two examples imply that migration projects are not to be treated as one time - one place decision but rather as a set of decisions whereas the motives and factors can change over time.

For this reason while analyzing the mobility of Polish graduates we will follow the typology of migrants as proposed by Faggian and McCann (2009) who assessed the student-graduate migration behaviour in Great Britain. They indentified five distinct types of sequential migration associated with this particular groups, namely:

1) Repeat migrants who moved away from their home areas to get education and then are moving to a third area after graduation;

2) Return migrants who moved away from their home areas to get education and then are returning in order to find gainful employment;

3) University stayers who moved away from their home areas to get education and then settle in the university / school area;

4) Late migrants who remain in the home area in order to enter education there and move away after graduation only; and

5) Non-migrants whose place of education and labour market entrance are the same as their domicile.

The above described typology allows for considering not only individual characteristics but also structural factors associated with both home areas, university areas and potential destinations. 
In conceptual terms we suggest to move beyond the traditional literature on migration propensity and to apply the migration capabilities approach as suggested by de Haas (2010). De Haas argues that migration decision on the individual level is to be analyzed as an outcome of two critical factors: capability for migration and aspirations to migrate. Czaika and Vothknecht (2014) move one step further and conceptualize migration as a function of individual's capability for migration being a combination of two capacities: capacity to aspire and capacity to realise.

The capacity to aspire goes beyond the simple microeconomic understanding of people as income maximizers. Authors argue that the capacity to aspire can be understood in terms of aspiration gap, i.e. the difference between individual's current level of well-being and aspired level of well-being:

$g_{i, t}\left(w_{i, t}^{a}, w_{i, t}\right) \equiv w_{i, t}^{a}-w_{i, t}$

Where: $g$ - aspiration gap, $w^{\text {a }}$ - aspired level of well- being, w - current level of well- being. In such a framework an individual with a particular level of subjective well-being can consider migration in order to achieve an aspired level of well-being (in time $t+1$ ). Importantly Czaika and Vothknecht (2014) argue that the capacity to aspire includes not only the ability to aspire but also knowledge how to achieve certain goals which implies that it can change over time, be inherited but also be a product of social environment (e.g. university, family home). Life aspirations may be a function of individual personality, socialization process, education, access to information and social capital, individual experience, media etc.

Apparently the migration decision is not only an outcome of aspirations but also a function of capabilities. Czaika and Vothknecht (2014) claim that the capacity to realize a certain migration project is a function of set of endowments with all possible forms of capitals or capabilities: economic, social, human and political. Moreover, in most cases lack of those capacities can severely hinder migration decision. In other words, a person with capacity to aspire is a potential migrant whose plans can never translate into real migration without sufficient capacities to realize. Migration capabilities framework is useful also because it assumes that both capacities described above are clearly mutually interdependent, e.g. certain aspirations can provide stimuli to improve the capabilities and aspirations can be a consequence of a set of capabilities (e.g. level of cultural capital). Moreover, both phenomena are expected to change over the life course and over the migration project of a given individual.

\section{Empirical strategy and data}


The main aim of the empirical analysis is to examine the role of a given set of characteristics on the migration propensity of Polish graduates. Following conceptual approach, as presented in section 2, we claim that independent variables used in the analysis may serve as proxies for capacities to aspire and capacities to realize the migration project by a given person. Second we attempt to investigate how those factors influence variety of migration behaviour as discussed before. While assessing the graduates' mobility we assume following:

1) Decision (propensity) to migrate depends on both factors to be assessed in terms of aspirations and capabilities (it is a function of capacity to aspire and capacity to realize).

2) Structure and importance of both capacities can change in the life course and along the education process. Thus we differentiate a few distinct types of sequential migration to be driven by various set of causal factors.

With regard to the first assumption and following literature review presented above we expect that propensity to migrate is correlated with:

1) Factors to be interpreted in terms of capacity to aspire: tertiary education (MA or higher grade), hometown characteristics to be interpreted in terms of aspirations gap (particularly: unemployment rate as variable indicating probability of finding employment), and reservation wage as a direct expression of monetary expectations (aspirations).

2) Factors to be assessed in terms of capacity to realize: previous migration experience (as a proxy for higher propensity to migrate and ability to take risks related to mobility), number of siblings (as a proxy for the ability of the family to co-finance change in the place of residence), secondary and tertiary school achievements as well as the quality of the higher education (index of quality attributed to a given school) to be interpreted in terms of employability, and selected measures of cultural capital (mother and/or father with tertiary education, number of books in the household).

Additionally we include in our econometric characteristics a set of socio-demographics (age, gender, marital status), variables related to the financial status of the family, status on the labour market (during the final year of studies) and selected characteristics of education obtained.

With regard to the second assumption we hypothesize that there is no common set of factors influencing various migration strategies (there are statistically significant differences between identified categories), and: 
1) Repeat migrants are driven predominantly by characteristics related to their level of aspirations.

2) Return migrants are driven by (low) capacities to realize the migration project and characteristics of the hometown (employability).

3) University stayers are driven by both capacity to aspire and capacity to realize and family related financial constraints.

4) Late migrants' propensity to migrate is correlated with aspirations and characteristics of the quality of school completed.

5) Non-migrants' decision to be immobile is driven particularly by low capacities in both dimensions conditional on hometown characteristics and educational offer in place, e.g. inhabitants of Warsaw and other large towns are to interpreted in different way than the other persons in the sample.

Thus our empirical aim is to examine the role of independent variables on migration status of Polish graduates. This status can be described as repeat migrants $(j=1)$, return migrants $(j=2)$, university stayers $(j=3)$, late migrants $(j=4)$ and non-migrants $(j=5)$. Let us assume that utilities corresponding with a given situation (migration status) are given by:

$$
U_{i j}=x_{i}^{\prime} \beta_{j}+\varepsilon_{i j}
$$

Where $\mathrm{x}$ is a vector of variables being proxies of capacities to aspire and to realize as well as control variables (including socio-demographic characteristics), $\beta_{j}$ is the coefficient corresponding to alternative $j$ and $\varepsilon_{i j}$ indicates the error term. In such a framework the probability of representing one of the migrant categories is determined by the pairwise comparison of utilities as given above (set of logits). If the error terms are independent and properly distributed, the probability of representing a given category of migrant $j$ (choosing one type of migration) can be expressed as a multinomial logit model in a following form (McFadden 1973; Long 1997):

$$
\operatorname{Prob}\left[y_{i}=j\right]=\frac{\exp \left(x_{i}^{i} \beta_{j}\right)}{\sum_{j=1}^{5}\left[x_{i}^{2} \beta_{j}\right]}, j=1, \ldots 5
$$

For identification purposes we will use the non-migrant category as a reference alternative.

We use a database constructed jointly by EUROREG, University of Warsaw and the Institute for Educational Research (IBE) in Warsaw. The survey research was performed on the sample of 5,800 
Polish citizens at the age of $25-30$, who attained at least full secondary education. The respondents were interviewed in 50 randomly chosen counties (out of total number of 380 counties in Poland). The survey dataset has been merged with selected data from the Local Data Bank (administered by the Central Statistical Office), with the outcomes of maturity examinations in upper secondary schools (provided by $\mathrm{IBE}$ ), and with the results of university ranking, administered by the independent web portal 'Perspektywy'.

For the purpose of this research the sample was restricted to individuals holding BA or MA degree, as we are interested in sequential migration behaviour of university graduates. Moreover, due to some difficulties with matching data on school quality (test scores) and the university rank with the main database, some observations had to be dropped. Ultimately, the model was estimated on 1,281 observations.

The explanatory variables used in the model specification are listed in table 1. To make the way we interpret particular variables more clear, the table is organized according to double classification. The variables are grouped by the type of characteristics they represent, thus into: respondent's individual and family characteristics, past migration experience, hometown characteristics, secondary school experience, tertiary education experience, and wage aspirations. Additionally, each variable was assigned a label $a, r$, or $c$, depending if we consider it as reflecting more for individual's capacity to aspire, to realize aspirations, or as a control variable.

Table 1. Explanatory variables

\begin{tabular}{|l|l|}
\hline Explanatory variable & $\begin{array}{l}\text { Capacity to } \\
\text { aspire/realize }\end{array}$ \\
\hline Individual/family characteristics & \\
\hline sex (m=1, f=2) & $\mathrm{c}$ \\
\hline married (yes=1) & $\mathrm{c}$ \\
\hline age of respondent & $\mathrm{c}$ \\
\hline mother with university degree (yes=1) & $\mathrm{r}$ \\
\hline mother with less than secondary education (yes=1) & $\mathrm{r}$ \\
\hline more than 200 books at home (yes=1) & $\mathrm{r}$ \\
\hline graduated primary school in Warsaw (yes=1) & $\mathrm{r}$ \\
\hline father's occupation high skilled white collar (yes=1) & $\mathrm{r}$ \\
\hline number of siblings & $\mathrm{r}$ \\
\hline birth order & $\mathrm{r}$ \\
\hline own room while in primary school (yes=1) & $\mathrm{r}$ \\
\hline own room while in secondary school (yes=1) & $\mathrm{r}$ \\
\hline Past migration experience & \\
\hline mother's family home more than 20 km from respondent's primary school (yes=1) & $\mathrm{r}$ \\
\hline distance between respondent's primary and secondary schools (km) & $\mathrm{r}$ \\
\hline Hometown characteristics & \\
\hline &
\end{tabular}




\begin{tabular}{|l|l|}
\hline population of municipality of origin & a \\
\hline unemployment rate in municipality of origin & a \\
\hline Secondary school characteristics/achievements & \multicolumn{2}{|l|}{} \\
\hline graduated from general secondary school (yes=1) & a \\
\hline average score on maturity exam in respondent's secondary school (math-science) & $\mathrm{r}$ \\
\hline average score on maturity exam in respondent's secondary school (humanistic) & $\mathrm{r}$ \\
\hline respondent exempted from any part of maturity examination (yes=1) & $\mathrm{r}$ \\
\hline Tertiary school characteristics/achievements & \\
\hline attended non-public tertiary school & \\
\hline graduated from MA program (yes=1) & $\mathrm{a}$ \\
\hline was employed during last year of university studies (yes=1) & $\mathrm{c}$ \\
\hline respondent's university quality indicator & $\mathrm{r}$ \\
\hline study field: science-engineering (yes=1) & $\mathrm{c}$ \\
\hline study field: social science (yes=1) & $\mathrm{c}$ \\
\hline noon-stationary mode of studying (yes=1) & $\mathrm{c}$ \\
\hline Wage aspirations & \\
\hline wage expected on respondent's post & $\mathrm{a}$ \\
\hline Source: own elaboration. & \multicolumn{2}{|l}{} \\
\hline
\end{tabular}

Source: own elaboration.

The dependent variable reflects the sequential migration decisions of individuals. It takes one of the five values: 0 - for non-migrants (reference category); 1 - for return migrants; 2 - for university stayers; 3 - for repeat migrants; and 4 - for late migrants. Table 2 includes descriptive statistics of the variables used in econometric modelling.

Table 2. Summary statistics

\begin{tabular}{|c|c|c|}
\hline Variable & Mean & St.dev. \\
\hline \multicolumn{3}{|l|}{ Dependent variable } \\
\hline Sequential migration behaviour & 1.058 & 1.092 \\
\hline \multicolumn{3}{|l|}{ Individual/family characteristics } \\
\hline $\operatorname{sex}(m=1, f=2)$ & 1.573 & 0.495 \\
\hline married (yes=1) & 0.379 & 0.485 \\
\hline age of respondent & 27.746 & 1.825 \\
\hline mother with university degree (yes=1) & 0.188 & 0.391 \\
\hline mother with less than secondary education (yes=1) & 0.268 & 0.443 \\
\hline more than 200 books at home (yes=1) & 0.158 & 0.365 \\
\hline graduated primary school in Warsaw (yes $=1$ ) & 0.115 & 0.320 \\
\hline father's occupation high skilled white collar (yes=1) & 0.214 & 0.410 \\
\hline number of siblings & 1.354 & 1.340 \\
\hline birth order & 1.779 & 4.699 \\
\hline own room while in primary school (yes=1) & 1.300 & 0.459 \\
\hline own room while in secondary school (yes=1) & 1.227 & 0.419 \\
\hline \multicolumn{3}{|l|}{ Past migration experience } \\
\hline $\begin{array}{l}\text { mother's family home more than } 20 \mathrm{~km} \text { from respondent's primary school } \\
\text { (yes=1) }\end{array}$ & 0.165 & 0.371 \\
\hline
\end{tabular}




\begin{tabular}{|c|c|c|}
\hline distance between respondent's primary and secondary schools $(\mathrm{km})$ & 11.139 & 38.884 \\
\hline \multicolumn{3}{|l|}{ Hometown characteristics } \\
\hline population of municipality of origin & 321442 & 530307 \\
\hline unemployment rate in municipality of origin & 12.987 & 6.925 \\
\hline \multicolumn{3}{|l|}{ Secondary school characteristics/achievements } \\
\hline graduated from general secondary school (yes=1) & 0.733 & 0.443 \\
\hline $\begin{array}{l}\text { average score on maturity exam in respondent's secondary school (math- } \\
\text { science) }\end{array}$ & 100.886 & 9.129 \\
\hline $\begin{array}{l}\text { average score on maturity exam in respondent's secondary school } \\
\text { (humanistic) }\end{array}$ & 100.467 & 6.990 \\
\hline respondent exempted from any part of maturity examination (yes=1) & 0.087 & 0.282 \\
\hline \multicolumn{3}{|l|}{ Tertiary school characteristics/achievements } \\
\hline attended non-public tertiary school & 0.232 & 0.422 \\
\hline graduated from MA program (yes=1) & 0.623 & 0.485 \\
\hline was employed during last year of university studies (yes=1) & 0.398 & 0.490 \\
\hline respondent's university quality indicator & 40.702 & 27.706 \\
\hline study field: science-engineering (yes=1) & 0.217 & 0.412 \\
\hline study field: social science (yes=1) & 0.300 & 0.458 \\
\hline noon-stationary mode of studying (yes=1) & 0.360 & 0.480 \\
\hline \multicolumn{3}{|l|}{ Wage aspirations } \\
\hline wage expected on respondent's post & 3481 & 2923 \\
\hline
\end{tabular}

Source: own elaboration.

Following Faggian and McCann (2009) we consider migration as a movement covering a distance of more than $15 \mathrm{~km}$. We assess individual sequential migration behaviour by mapping the localities in which he or she has graduated from primary school (earliest location available in our dataset), graduated from university and lived at the moment survey is taken. Only individuals who already terminated their school education were included in the sample. For example, a return migrant is an individual, whose university was located more than $15 \mathrm{~km}$ away from his or her primary school, and his/her ultimate place of residence is less than $15 \mathrm{~km}$ away from the primary school.

Naturally, by focusing on schools' locations as criteria to assess migration we consider permanent and circular mobility as equal phenomenon. In other words, individuals who do not change their place of residence, but decide to commute (on daily basis) to school located more than $15 \mathrm{~km}$ away are equivalent to those who physically move for more than $15 \mathrm{~km}$ in order to attend this school ${ }^{2}$.

The model has been subject to some diagnostic checks. One of the popular scalar measures of fit for the multinomial logistic regression is McFadden's R2. According to Mc Fadden (1978), the rule of thumb is that pseudo $R^{2}$ should be between 0.2 and 0.4 for such models and in our case it exactly fits the interval $(0.3483)$, which suggests that the model fits the data relatively well. The Hausman-

\footnotetext{
${ }^{2}$ This is a very strong assumption which we plan to relax, and discuss more deeply in further versions of this paper.
} 
McFadden test for Independence of Irrelevant Alternatives was performed, but its result was not satisfactory. We obtained a negative outcome, in contradiction of the asymptotic chi-square distribution of the test statistic. Similar result is confirmed by many other researchers using this test. Long and Freese (2006) do not encourage to use common IIA tests (McFadden and Small-Hsiao) and indicate that there seems to be no reliable test of the IIA assumption.

Using the estimated coefficients one can also generate predicted probabilities to better understand the model and its fit. Based on the predicted probabilities calculated for each observation and each alternative we generated in-sample predictions of the migration status (based on the alternative with the highest probability on the observation level) and compared them with the observed values of migration status by a so called confusion matrix (two-way frequency table).

The percentage of correctly predicted level is quite high and equals to $70.5 \%$ (for 903 observations the in-sample prediction is correct). However, it seems that that the model in fact predicts well just two levels of the migration status - non-migrants and repeat migrants $(82.6 \%$ and $91.3 \%$ of correct predictions). The model rarely predicts return migrants (only $0.9 \%$ share in predictions while $6.8 \%$ in actual values - only $4.6 \%$ of predictions are correct for this group) and university stayers (1.9\% share in predictions and $8 \%$ share in actual values $-5.9 \%$ of predictions are correct) and never predicts late migrants which cover $5.2 \%$ of the sample (67 observations).

To verify the above findings we decided to perform a leave-one-out cross-validation of the model. It requires estimating the model $n$-times, where $n$ is the number of observations. In each estimation one of the observations is left out and not used in estimation. Then based on the estimated coefficients the out-of-sample prediction is performed for this single observation. The procedure is repeated for each observation in the sample. The results are not very different from the in-sample predictions. The percentage of correctly predicted level is again quite high and equals to $70.3 \%$ (for 900 observations the out-of-sample prediction is correct). It is corroborated that the model in fact predicts well just two levels of the migration status - non-migrants and repeat migrants. In contrast to in-sample prediction results, here the model slightly better predicts late migrants - they cover $5.2 \%$ of the sample (67 observations) and the model predicts this status in $1.9 \%$ of cases. The prediction is correct for $19.4 \%$ of actual late migrants.

Based on the results of the confusion matrices test we can see that the model in its current shape is somehow biased towards predicting repeat migrants more often that they appear in the sample. Further work will have to be aimed at finding explanatory variables which better explain the behaviour of the return migrants and university stayers. 


\section{Results}

Table 5 (in the appendix) shows the full results of multinomial logit model. In order to keep our interpretation clear and relatively straightforward we present the results in a following way. First, we summarize the main outcomes in bullet points, with reference to the simplified table 3 , indicating only the significance and sign of selected variables separately for each value of the dependent variable (type of sequential migration behaviour). The variables included in table 3 are those turning out significant at $\mathrm{a}=0.01$ for at least one type of migration behaviour. Then we try to address the problem of interpretation of logit model coefficients. A disadvantage of using multinomial logit is that the model coefficients themselves do not have any direct meaning. Intuitively, these are probabilities that we are interested in, not the log odds of an event. Difficulties in logit interpretation are more profoundly discussed by Norton, Wang et.al (2004). One way to overcome this shortcoming is to compute the estimated (conditional) probabilities for some values of the independent variables (for algebraic details see Stata Library (2011). We attempt do this in table 3), for the same variables which were earlier included in table 3.

Table 3. Signs and significance level of the selected explanatory variables - by type of sequential migration behaviour (reference category: non-migrant)

\begin{tabular}{|c|c|c|c|c|}
\hline Variable & $\begin{array}{l}\text { return } \\
\text { migration }\end{array}$ & $\begin{array}{l}\text { university } \\
\text { staying }\end{array}$ & $\begin{array}{l}\text { repeat } \\
\text { migration }\end{array}$ & $\begin{array}{l}\text { late } \\
\text { migration }\end{array}$ \\
\hline \multicolumn{5}{|l|}{ Individual/family characteristics } \\
\hline mother with university degree $(r)$ & & & $-{ }^{* * *}$ & \\
\hline mother with less than secondary education $(r)$ & & & $+{ }^{*}$ & \\
\hline graduated from primary school in Warsaw $(r)$ & $++^{* * *}$ & $++^{* * *}$ & $+^{* *}$ & \\
\hline \multicolumn{5}{|l|}{ Past migration experience } \\
\hline mother's migration experience $(r)$ & $++^{* *}$ & $++^{* *}$ & $+{ }^{* * *}$ & \\
\hline distance between primary and secondary school $(r)$ & $++^{* *}$ & $++^{*}$ & $++^{* * *}$ & $++^{* * *}$ \\
\hline \multicolumn{5}{|l|}{ Hometown characteristics } \\
\hline population of municipality (a) & $-{ }^{*}$ & $--^{* *}$ & $-{ }^{* *}$ & \\
\hline unemployment (a) & $++^{* * *}$ & $+t^{* * *}$ & $++^{* * *}$ & \\
\hline \multicolumn{5}{|l|}{ Secondary school characteristics/achievements } \\
\hline general secondary school (a) & $+{ }^{*}$ & $+{ }^{*}$ & & \\
\hline \multicolumn{5}{|l|}{ Tertiary school characteristics/achievements } \\
\hline employed during studies (c) & $+{ }^{* *}$ & $+{ }^{* *}$ & & \\
\hline university quality (r) & $+{ }^{* * *}$ & $++^{* * *}$ & $++^{* * *}$ & \\
\hline graduated MA (a) & & $++^{* *}$ & $++^{* *}$ & $++^{* *}$ \\
\hline
\end{tabular}




\begin{tabular}{|l|l|l|l|l|}
\hline social science (c) & & $+{ }^{* *}$ & & \\
\hline Wage aspirations & & & $+^{*}$ & \\
\hline reservation wage (a) & & & \\
\hline
\end{tabular}

Source: own elaboration.

Overall, the main findings from the model estimation can be summarized as follows:

- The model, in its current specification, allows to identify several factors associated with return migration, university staying, and repeat migration. It however fails to explain the phenomenon of late migration.

- Following the classification of explanatory variables presented in section 3 we may conclude that both aspirations and capacity to realize them matter with respect to migrations of skilled, young individuals.

- Impossibility of realizing aspirations in the place of origin (proxied by hometown population and unemployment rate) is a strong push factor, increasing the propensity to migrate early (before tertiary education is completed), but with no impact on late migration.

- However, somehow surprisingly, attending primary school in Warsaw is also associated with higher mobility, particularly within return migration and university stayer categories.

- Past migration experience (both in the phase of secondary education and parents' generation) increase the probability of all types of sequential migration, with particularly strong impact on repeat migration. This in turn shows that ability to take (and to control) risk related to mobility plays a crucial role in migration decision making.

- Graduating from MA programme supports all type of migration behaviour but return migration. Graduating from better university is also associated with higher mobility. It increases the likelihood of return migration, university staying, and repeat migration.

- Employment during studies works in favour of university staying strategy. I also increases the probability of return migration, but not repeat migration or late mobility.

- Studying social sciences are more likely to become university stayers.

- Wage aspirations have only weak, positive association with repeat migration, but they are not statistically related to other types of sequential migration behaviour.

Table 4 describes the effects of change in the values of selected variables (same as presented in table 3) on the conditional probability of particular migration behaviours. Expressing the impact of different factors in terms of probability allows us to assess the real (and not just statistical) significance of the observed phenomena. As we can see, having highly educated mother has negligible effect on most migration behaviours, with the exception of repeat migration, for which the 
impact of maternal educational attainment is negative. More precisely, having mother with only primary education increases probability of repeat migration by 13 percentage points, while having mother with university degree decreases this probability by 24 percentage points. Interestingly thus, parental education does not reflect here a capacity to realize aspirations (as we assumed in table 1), but rather capacity to aspire. High family human capital provides a disincentive against migration, rather than inducing it which may reflect relatively higher chances to find employment without necessity to be mobile.

Table 4. Effect of change in the values of selected variables on the conditional probability of migration behaviour (in percentage points)

\begin{tabular}{|c|c|c|c|c|c|}
\hline \multirow[t]{2}{*}{ Variable } & \multirow{2}{*}{$\begin{array}{l}\text { Value } \\
\text { change }\end{array}$} & \multicolumn{4}{|c|}{ change of the conditional probability of (in pp): } \\
\hline & & $\begin{array}{l}\text { return } \\
\text { migration }\end{array}$ & $\begin{array}{l}\text { university } \\
\text { staying }\end{array}$ & $\begin{array}{l}\text { repeat } \\
\text { migration }\end{array}$ & $\begin{array}{l}\text { late } \\
\text { migration }\end{array}$ \\
\hline \multicolumn{6}{|l|}{ Individual/family characteristics } \\
\hline mother with university degree $(r)$ & $0 \rightarrow 1$ & -7.6 & -1.9 & -23.7 & -9.7 \\
\hline $\begin{array}{l}\text { mother with less than secondary } \\
\text { education }(r)\end{array}$ & $0 \rightarrow 1$ & +4.4 & +5.4 & +13.4 & +6.3 \\
\hline $\begin{array}{l}\text { graduated from primary school in } \\
\text { Warsaw }(r)\end{array}$ & $0 \rightarrow 1$ & +41.4 & +92.8 & +68.2 & -14.1 \\
\hline \multicolumn{6}{|l|}{ Past migration experience } \\
\hline mother's migration experience $(r)$ & $0 \rightarrow 1$ & +10.7 & +18.3 & +35.3 & $-0.8 \%$ \\
\hline $\begin{array}{l}\text { distance between primary and } \\
\text { secondary school }(r)\end{array}$ & $0 \rightarrow 20$ & +6.2 & +9.9 & +14.6 & +9.6 \\
\hline \multicolumn{6}{|l|}{ Hometown characteristics } \\
\hline population of municipality (a) & $10 k \rightarrow 100 k$ & -3.6 & -16.9 & -10.1 & -1.1 \\
\hline unemployment (a) & $5 \% \rightarrow 10 \%$ & +22.2 & +5.7 & +11.7 & +2.7 \\
\hline \multicolumn{6}{|c|}{ Secondary school characteristics/achievements } \\
\hline general secondary school (a) & $0 \rightarrow 1$ & +8.9 & +10.4 & +1.8 & $+0.3 \%$ \\
\hline \multicolumn{6}{|c|}{ Tertiary school characteristics/achievements } \\
\hline employed during studies (c) & $0 \rightarrow 1$ & +8.9 & +11.2 & +8.9 & +7.9 \\
\hline university quality $(r)$ & $75 \rightarrow 25$ & +24.6 & +15.5 & +23.9 & +6.1 \\
\hline graduated MA (a) & $0 \rightarrow 1$ & +17.0 & +11.9 & +12.6 & +9.2 \\
\hline social science (c) & $0 \rightarrow 1$ & +4.9 & +12.3 & -0.2 & -2.8 \\
\hline
\end{tabular}

Source: own elaboration.

Past migration experience have strongest (positive) effect on the mobility of skilled individuals within the categories of university stayers and repeat migrants. Mother's migration experience increases the likelihood of child's choice of repeat migration by 35 points, and the probability of university staying - by 18 points. Also individual's own experience with mobility, proxied by the distance 
between primary and secondary school location, makes further migration more probable. Comparing two hypothetical and otherwise identical individuals, one of which has graduated from primary and secondary school in the same town (0 km distance), and the second, for whom the respective distance was $20 \mathrm{~km}$, we observe the probability of any further migration being higher for the latter individual. The difference ranges from 6 to 15 percentage points depending on considered sequential migration type.

Graduating from primary school in a large city makes an individual less prone to migrate. A hypothetical difference between somebody growing up in a city with the population of 100,000 , as compared to an individual originating from a town with 10,000 inhabitants, is transformed into a 17 points gap in the probability of belonging to university stayer category, and a 10 points difference in the probability of repeat migration. This outcome is well understandable if we interpret it in terms of push factors or relatively lower aspiration gap to be expected in case of inhabitants of large cities.

In turn, unemployment seems to be very strong factor pushing for migration on one hand, but on another it is particularly often associated with a failure to permanently break up from adverse environment. A $5 \%$ increase in unemployment rate in the town where an individual has graduated from primary school is transformed into 22 percentage points increase of the probability of return migration, and a 12 percentage points rise in the probability of repeat migration. The effect on university staying or late migration is positive, but modest in magnitude.

The impact of MA aspirations on the propensity to migrate turns out to be positive, with comparable magnitude (12pp-17pp) of the effect on return migration, university staying and repeat migration, although, as shown in table 3 , the coefficient for return migration is not significant. This is a particularly interesting outcome considering very vital debate on the importance of tertiary education (and as we assume - the aspiration level) for the recent mobility of Poles (Kaczmarczyk and Okólski 2008; Grabowska and Okólski 2009).

Finally, attending a university of high quality (high ranking) is positively correlated with the probability of both early, and late migration. Table 4 illustrates this effect showing the difference between a university at the first versus third quartile, according to the quality ranking. As it turns out, attending better university is associated with the probability of return migration increased by 25 percentage points, and the probability of repeat migration shifted up by 24 percentage points. The positive effect on university staying is smaller (15 percentage points), but still highly significant. One may argue that high quality university education impacts positively both on capacity to aspire and capacity to realize a given migration project. 


\section{Conclusions}

An aim of this paper was to discuss the drivers of high skilled migration, with a focus on internal mobility of Polish graduates. With respect to research hypotheses formulated in section 3 of the paper, we find only partial confirmation of our intuitions. We expected repeat migration to be driven predominantly by characteristics related to the level of aspirations. And indeed, the probability of becoming a repeat migrant turned out to be positively affected by such aspiration related factors as hometown characteristics, attending an MA program, or wage ambitions measured by the reservation wage. Moreover, repeat migration seems also to depend negatively on the family human capital, which suggests that individuals from low educated families may be more mobile in search for employment opportunities. At the same time however, probability of repeat migration is clearly conditioned on the capacity to realize aspirations. It depends on migration experience of the family in the previous generation, and on the mobility of an individual at the early stages of education. It is also positively correlated to the quality of the attended university. This result shows that contrary to our intuitions capacities to aspire and capacities to realize are not separable as drivers of migratory behaviour (even if their importance can be different in case of particular migration strategies).

Return migration was expected to be driven by (low) capacities to realize the migration project and characteristics of the hometown (employability). Indeed, unemployment in the town of origin significantly affects return migration, but the sign of this effect is positive, indicating that migrants are likely to return to localities with low employment opportunities. Even more surprisingly, the probability of return migration depends positively on some factors related to individual's capability, such as the quality of university and past migration experience, including this in previous generation. Return migration is also positively associated with employment during studies which can be explained in terms of financial capital gained through gainful employment before return (during studies) or relatively better orientation on the labour market. It seems that return migration category requires careful reconsideration and further analytical work. It is likely that the obtained results are partly driven by the fact that this type of sequential migration behaviour include circular mobility in the proximity of large cities. In reality however such migration is for many reasons very different from a permanent move to the city, and eventual return to the hometown.

In accordance with expectations, the strategy of university staying is positively related to both individual's capacity to aspire and capacity to realize. Being raised in a small town, with poor employment prospects acts as a strong push factor, increasing the propensity to university staying. 
Moreover, the ability to remain in the city of studies seems to significantly depend on the university career of an individual. Enrolling to a good university, graduating from MA program, starting professional career during studies are all events which positively affect the probability of university staying. Another positive determinant is past migration experience.

University staying is the only migration strategy with the significant effect of the field of studies. Graduates of social sciences programs are more likely to belong to this category than the graduates of other faculties. A dominant role of specialized services in the labour markets structure of large cities seems to be decisive factor here.

The phenomenon of late migration is largely unexplained by our model. More work needs to be done on model specification, as well as to increase the sample (currently less than 200 late migrants are included) to obtain a statistically significant results.

Finally, the interpretation of non-migrant category comes as 'residual' with respect to other types of migration behaviour, as non-migrants were the reference category in model estimation. It seems that the category is not homogenous. Some non-migrants decide to be immobile since they live in large cities with good local employment prospects. We might summarize their behaviour as no-needto-aspire, and thus - no migration. On the other hand, immobility is associated with low quality of the attended university, and is more likely to be observed in the families without past migratory traditions. Therefore, there are reasons to claim that immobility might also be driven by the lack of capacity to realize aspirations. 


\section{References}

Anacka M. (2010). „Poakcesyjne migracje Polaków - ciągłość czy zmiana?” Studia Migracyjne Przegląd Polonijny 4: 37-54.

Anacka M., Okólski M. (2010). Direct demographic consequences of post-accession migration for Poland. In: R. Black, G. Engbersen, M. Okólski, C. Panţǐru (eds), A Continent Moving West? Amsterdam: Amsterdam University Press, pp. 141-164.

Borjas, G.J. (1994). "The Economics of Immigration." Journal of Economic Literature 32: 1667-1717.

Burda, M. (1995). Migration and the Option Value of Waiting. CEPR Discussion Papers No. 1229.

Carletto, G., Davis, B., M. Stampini, S. Trento and A. Zezza (2004). Internal Mobility and International Migration. ESA Working Paper 04-13, FAO: Rome.

Czaika, M. (2011). Internal and international migration as response of double deprivation: some evidence from India, Proceedings of the German Development Economics Conference, Berlin 2011, No. 21.

Czaika, M. and M. Vothknecht (2014). "Migration and aspirations - are migrants trapped on a hedonic treadmill?" IZA Journal of Migration 3:1.

DaVanzo, J. (1981). Microeconomic Approaches to Studying Migration Decisions. In: Migration Decision Making: Multidisciplinary Approaches to Microlevel Studies in Developed and Developing Countries, edited by R.W. Gardner. New York: Pergamon Press.

Delisle, F. o. and R. Shearmur (2010). "Where does all the talent flow? Migration of young graduates and nongraduates, Canada 1996-2001." Canadian Geographer / Le GĂ@ographe canadien 54(3): 305-323.

Faggian, A. and P. McCann (2007). "Some evidence that women are more mobile than men: Gender differences in U.K. graduate migration behavior." Journal of Regional Science 47(3): 517-539.

Faggian, A. and P. McCann (2009). "Human capital, graduate migration and innovation in British regions." Cambridge Journal of Economics 33(2): 317-333.

Faggian, A., P. McCann, et al. (2006). "An analysis of ethnic differences in UK graduate migration behaviour." The Annals of Regional Science 40(2): 461-471.

Fawcett, J.T. (1987). "Networks, Linkages and Migration Systems." International Migration Review 23(3): 671-680.

Gibbons, S. and A. Vignoles (2012). "Geography, choice and participation in higher education in England." Regional Science and Urban Economics 42(1-2): 98-113.

Gottlieb, P.D. and G. Joseph (2006). College-to-work Migration of Technology Graduates and Holders of Doctorates within the United States. Journal of Regional Studies 46(4): 627-659.

Grabowska, I. and M. Okolski (2009). Migracja ostatnia? Warsaw: Scholar.

Haapanen, M. and H. Tervo (2011). "Migration of the Highly Educated: Evidence From Residence Spells of University Graduates." Journal of Regional Science 51(5): 1-19.

de Haas, H. (2010). Migration and Development - A Theoretical Perspective. International Migration Review 44(1): 227-264.

Harris, J. and M. Todaro (1970). "Migration, Unemployment \& Development: A Two-Sector Analysis." American Economic Review 60(1): 126-142.

Hatton, T. J. and J.Williamson (2002). What Fundamentals Drive World Migration? CEPR Discussion Papers 3559. 
Herbst, M. (2010). "Creation and Absorption of Human Capital by Academic Cities in Poland." Studia Regionalne i Lokalne(special issue): 59-76.

Herbst, M. and J. Rok (2013). Mobility of human capital and its effect on regional economic development. Review of theory and empirical literature. MPRA Paper 45755, University Library of Munich, Germany.

Herbst, M. and J. Rok (2014). Drivers and patterns of student and graduate mobility. Evidence from social media network. Warsaw, EUROREG, University of Warsaw.

Hicks, J. (1932). The Theory of Wages. London: Macmillan.

Kaczmarczyk, P. (2005). Migracje zarobkowe Polaków w dobie przemian. Warsaw: Wydawnictwa Uniwersytetu Warszawskiego.

Kaczmarczyk, P. and M. Okólski (2008). "Demographic and economic impacts of Migration on Poland." Oxford Review of Economic Policy 24(3), 600-625.

Kodrzycki, Y. K. (2001). "Migration of Recent College Graduates : Evidence from the National Longitudinal Survey of Youth." New England Economic Review(1): 13-34.

Kwiek M. (2011). "The public/private dynamics in Polish higher education: Demand-absorbing private growth and its implications", Higher Education Forum 8: 37-59

Long, J.S. (1997). Regression Models for Categorical and Limited Dependent Variables. Thousand Oaks: Sage.

Long, J.S. and J. Freese. (2006). "Regression Models for Categorical Dependent Variables Using Stata", 2nd ed. College Station, TX: Stata Press.

Mincer, J. (1978). “Family Migration Decisions." Journal of Political Economy 86(5):749-773.

Molho, I. (1986). "Theories of Migration - A Review." Journal of Political Economy 60(5): 557-559.

Mosca, I. and R. E. Wright (2010). "National and international graduate migration flows." Population trends (141): 36-53.

Mundell, R. (1957). "International Trade and Factor Mobility." American Economic Review 47(3): 321335.

Newbold, K. B. (2001). "Counting Migrants and Migrations: Comparing Lifetime and Fixed-Interval Return and Onward Migration." Economic Geography 77: 23-40.

Quinn, M. (2006). "Relative deprivation, wage differentials and Mexican migration." Review of Development Economics 10: 135-53.

Samuelson, P. (1948). "International Trade and the Equalisation of Factor Prices." Economic Journal 58: 163-184.

Sjaastad, L. A. (1962). "The costs and returns of human migration." Journal of Political Economy 70: 80-93.

Stark, O. (1984). "Rural to Urban Migration in LDCs: A Relative Deprivation Approach." Economic Development and Cultural Change 32: 475-86.

Stark, O. and E.J. Taylor (1991a). Relative deprivation and migration : theory, evidence, and policy implications. Policy Research Working Paper Series 656, The World Bank.

Stark, O. and E.J. Taylor (1991b). "Migration Incentives, Migration Types: The Role of Relative Deprivation." Economic Journal 101(408): 1163-78.

Stark, O. and E.J. Taylor (1989). "Relative deprivation and international migration." Demography 26(1): 1-14 
Stark, O. and D.E. Bloom (1985). "The New Economics of Labor Migration." American Economic Review 75(2): 173-178.

Venhorst, V., J. Van Dijk, et al. (2010). "Do the Best Graduates Leave the Peripheral Areas of the Netherlands?" Tijdschrift voor economische en sociale geografie 101(5): 521-537.

Wulff, M., and Dharmalingam, A. (2008). "Retaining Skilled Migrants in Regional Australia: The Role of Social Connectedness." Journal of International Migration and Integration 9(2): 147-160. 


\section{Appendix}

Table 5. Full results of the multinomial logit model (non-migrant as reference category)

\begin{tabular}{|c|c|c|c|c|c|c|}
\hline & Coef. & Std. Err. & $z$ & $P>z$ & $\begin{array}{l}{[95 \%} \\
\text { Conf. }\end{array}$ & Interval] \\
\hline \multicolumn{7}{|l|}{ Return migrants } \\
\hline \multicolumn{7}{|l|}{ Individual/family characteristics } \\
\hline sex & 0.038 & 0.215 & 0.180 & 0.859 & -0.383 & 0.459 \\
\hline married & -0.215 & 0.214 & -1.000 & 0.317 & -0.635 & 0.206 \\
\hline age & -1.501 & 2.001 & -0.750 & 0.453 & -5.423 & 2.421 \\
\hline age_square & 0.027 & 0.036 & 0.740 & 0.459 & -0.044 & 0.098 \\
\hline mother with university degree & -0.369 & 0.270 & -1.370 & 0.171 & -0.897 & 0.160 \\
\hline $\begin{array}{l}\text { mother with less than secondary } \\
\text { education }\end{array}$ & 0.230 & 0.248 & 0.930 & 0.353 & -0.255 & 0.716 \\
\hline more than 200 books at home & -0.066 & 0.281 & -0.240 & 0.814 & -0.616 & 0.484 \\
\hline graduated primary school in Warsaw & 6.223 & 1.101 & 5.650 & 0.000 & 4.065 & 8.381 \\
\hline father - high skilled white collar & 0.178 & 0.257 & 0.690 & 0.489 & -0.325 & 0.680 \\
\hline number of siblings & -0.085 & 0.078 & -1.090 & 0.274 & -0.237 & 0.067 \\
\hline birth order & -0.001 & 0.003 & -0.320 & 0.745 & -0.006 & 0.005 \\
\hline own room (primary) & -0.360 & 0.350 & -1.030 & 0.303 & -1.045 & 0.325 \\
\hline own room (secondary) & 0.330 & 0.374 & 0.880 & 0.378 & -0.403 & 1.062 \\
\hline \multicolumn{7}{|l|}{ Past migration experience } \\
\hline mother's migration & 0.609 & 0.257 & 2.370 & 0.018 & 0.105 & 1.113 \\
\hline $\begin{array}{l}\text { distance between primary and } \\
\text { secondary schools }\end{array}$ & 0.016 & 0.006 & 2.480 & 0.013 & 0.003 & 0.028 \\
\hline \multicolumn{7}{|l|}{ Hometown characteristics } \\
\hline population of municipality & 0.000 & 0.000 & -10.870 & 0.000 & 0.000 & 0.000 \\
\hline unemployment & 0.180 & 0.024 & 7.520 & 0.000 & 0.133 & 0.227 \\
\hline \multicolumn{7}{|c|}{ Secondary school characteristics/achievements } \\
\hline general secondary school & 0.436 & 0.248 & 1.760 & 0.079 & -0.050 & 0.922 \\
\hline maturity score (math-science) & -0.014 & 0.024 & -0.600 & 0.548 & -0.061 & 0.032 \\
\hline maturity score (humanistic) & 0.017 & 0.031 & 0.550 & 0.581 & -0.044 & 0.079 \\
\hline exempted from maturity exam & 0.457 & 0.354 & 1.290 & 0.197 & -0.237 & 1.151 \\
\hline \multicolumn{7}{|c|}{ Tertiary school characteristics/achievements } \\
\hline non-public tertiary & 0.142 & 0.299 & 0.470 & 0.636 & -0.445 & 0.729 \\
\hline graduated MA & 0.837 & 0.214 & 3.910 & 0.000 & 0.417 & 1.258 \\
\hline employed during studies & 0.465 & 0.224 & 2.080 & 0.038 & 0.026 & 0.903 \\
\hline university quality & -0.023 & 0.004 & -5.790 & 0.000 & -0.031 & -0.015 \\
\hline science-engineering & 0.084 & 0.246 & 0.340 & 0.732 & -0.398 & 0.567 \\
\hline social science & 0.256 & 0.238 & 1.080 & 0.282 & -0.211 & 0.724 \\
\hline non-stationary & 0.297 & 0.259 & 1.150 & 0.251 & -0.211 & 0.806 \\
\hline \multicolumn{7}{|l|}{ Wage aspirations } \\
\hline reservation wage & 0.000 & 0.000 & 0.300 & 0.762 & 0.000 & 0.000 \\
\hline constant & 20.194 & 27.508 & 0.730 & 0.463 & -33.721 & 74.108 \\
\hline
\end{tabular}




\begin{tabular}{|c|c|c|c|c|c|c|}
\hline \multicolumn{7}{|l|}{ University stayers } \\
\hline \multicolumn{7}{|l|}{ Individual/family characteristics } \\
\hline sex & 0.233 & 0.372 & 0.630 & 0.531 & -0.496 & 0.962 \\
\hline Married & 0.048 & 0.348 & 0.140 & 0.891 & -0.635 & 0.731 \\
\hline age & 0.258 & 3.487 & 0.070 & 0.941 & -6.575 & 7.092 \\
\hline age_square & -0.002 & 0.063 & -0.040 & 0.970 & -0.126 & 0.121 \\
\hline mother with university degree & -0.143 & 0.443 & -0.320 & 0.746 & -1.011 & 0.724 \\
\hline $\begin{array}{l}\text { mother with less than secondary } \\
\text { education }\end{array}$ & 0.368 & 0.411 & 0.900 & 0.371 & -0.438 & 1.174 \\
\hline more than 200 books at home & 0.675 & 0.428 & 1.580 & 0.114 & -0.163 & 1.513 \\
\hline graduated primary school in Warsaw & 9.124 & 3.107 & 2.940 & 0.003 & 3.034 & 15.215 \\
\hline father - high skilled white collar & -0.210 & 0.435 & -0.480 & 0.630 & -1.063 & 0.644 \\
\hline number of siblings & -0.062 & 0.147 & -0.420 & 0.673 & -0.351 & 0.227 \\
\hline birth order & -0.005 & 0.005 & -0.880 & 0.381 & -0.015 & 0.006 \\
\hline own room (primary) & -1.005 & 0.648 & -1.550 & 0.121 & -2.275 & 0.264 \\
\hline own room (secondary) & 0.937 & 0.671 & 1.400 & 0.163 & -0.378 & 2.253 \\
\hline \multicolumn{7}{|l|}{ Past migration experience } \\
\hline mother's migration & 1.055 & 0.419 & 2.520 & 0.012 & 0.233 & 1.876 \\
\hline $\begin{array}{l}\text { distance between primary and } \\
\text { secondary schools }\end{array}$ & 0.036 & 0.007 & 5.380 & 0.000 & 0.023 & 0.049 \\
\hline \multicolumn{7}{|l|}{ Hometown characteristics } \\
\hline population of municipality & 0.000 & 0.000 & -4.210 & 0.000 & 0.000 & 0.000 \\
\hline unemployment & 0.258 & 0.033 & 7.820 & 0.000 & 0.193 & 0.322 \\
\hline \multicolumn{7}{|c|}{ Secondary school characteristics/achievements } \\
\hline general secondary school & 0.828 & 0.432 & 1.920 & 0.055 & -0.018 & 1.675 \\
\hline maturity score (math-science) & 0.007 & 0.043 & 0.170 & 0.868 & -0.078 & 0.092 \\
\hline maturity score (humanistic) & -0.020 & 0.055 & -0.360 & 0.722 & -0.128 & 0.089 \\
\hline exempted from maturity exam & 0.133 & 0.578 & 0.230 & 0.818 & -1.000 & 1.266 \\
\hline \multicolumn{7}{|c|}{ Tertiary school characteristics/achievements } \\
\hline non-public tertiary & 0.407 & 0.478 & 0.850 & 0.394 & -0.530 & 1.344 \\
\hline graduated MA & 0.907 & 0.391 & 2.320 & 0.020 & 0.140 & 1.674 \\
\hline employed during studies & 0.764 & 0.356 & 2.150 & 0.032 & 0.067 & 1.461 \\
\hline university quality & -0.026 & 0.007 & -3.890 & 0.000 & -0.038 & -0.013 \\
\hline science-engineering & 0.483 & 0.439 & 1.100 & 0.271 & -0.378 & 1.344 \\
\hline social science & 0.795 & 0.386 & 2.060 & 0.039 & 0.038 & 1.552 \\
\hline non-stationary & -0.479 & 0.424 & -1.130 & 0.259 & -1.310 & 0.353 \\
\hline \multicolumn{7}{|l|}{ Wage aspirations } \\
\hline reservation wage & 0.000 & 0.000 & 1.570 & 0.117 & 0.000 & 0.000 \\
\hline constant & -9.428 & 48.209 & -0.200 & 0.845 & -103.915 & 85.059 \\
\hline \multicolumn{7}{|l|}{ Repeat migrants } \\
\hline \multicolumn{7}{|l|}{ Individual/family characteristics } \\
\hline sex & 0.360 & 0.304 & 1.180 & 0.236 & -0.236 & 0.955 \\
\hline married & 0.182 & 0.287 & 0.640 & 0.525 & -0.380 & 0.744 \\
\hline age & -1.335 & 2.792 & -0.480 & 0.633 & -6.807 & 4.138 \\
\hline age_square & 0.026 & 0.051 & 0.510 & 0.610 & -0.073 & 0.125 \\
\hline
\end{tabular}




\begin{tabular}{|c|c|c|c|c|c|c|}
\hline mother with university degree & -1.318 & 0.437 & -3.020 & 0.003 & -2.173 & -0.462 \\
\hline $\begin{array}{l}\text { mother with less than secondary } \\
\text { education }\end{array}$ & 0.592 & 0.319 & 1.860 & 0.064 & -0.033 & 1.218 \\
\hline more than 200 books at home & 0.330 & 0.377 & 0.880 & 0.381 & -0.409 & 1.069 \\
\hline graduated primary school in Warsaw & 3.653 & 1.679 & 2.180 & 0.030 & 0.363 & 6.943 \\
\hline father - high skilled white collar & 0.242 & 0.356 & 0.680 & 0.497 & -0.456 & 0.939 \\
\hline number of siblings & -0.026 & 0.104 & -0.250 & 0.804 & -0.230 & 0.179 \\
\hline birth order & -0.002 & 0.004 & -0.470 & 0.638 & -0.010 & 0.006 \\
\hline own room (primary) & -0.590 & 0.477 & -1.240 & 0.216 & -1.525 & 0.345 \\
\hline own room (secondary) & 0.211 & 0.518 & 0.410 & 0.683 & -0.804 & 1.227 \\
\hline \multicolumn{7}{|l|}{ Past migration experience } \\
\hline mother's migration & 1.495 & 0.329 & 4.550 & 0.000 & 0.851 & 2.139 \\
\hline $\begin{array}{l}\text { distance between primary and } \\
\text { secondary schools }\end{array}$ & 0.034 & 0.006 & 5.670 & 0.000 & 0.022 & 0.046 \\
\hline \multicolumn{7}{|c|}{ Hometown characteristics } \\
\hline population of municipality & 0.000 & 0.000 & -5.290 & 0.000 & 0.000 & 0.000 \\
\hline \begin{tabular}{l|l} 
unemployment \\
\end{tabular} & 0.210 & 0.029 & 7.290 & 0.000 & 0.153 & 0.266 \\
\hline \multicolumn{7}{|c|}{ Secondary school characteristics/achievements } \\
\hline general secondary school & 0.081 & 0.331 & 0.250 & 0.806 & -0.568 & 0.731 \\
\hline maturity score (math-science) & -0.038 & 0.033 & -1.140 & 0.256 & -0.103 & 0.027 \\
\hline maturity score (humanistic) & 0.051 & 0.043 & 1.190 & 0.233 & -0.033 & 0.136 \\
\hline exempted from maturity exam & 0.642 & 0.456 & 1.410 & 0.159 & -0.251 & 1.535 \\
\hline \multicolumn{7}{|c|}{ Tertiary school characteristics/achievements } \\
\hline non-public tertiary & 0.092 & 0.401 & 0.230 & 0.818 & -0.694 & 0.878 \\
\hline graduated MA & 0.597 & 0.294 & 2.030 & 0.042 & 0.022 & 1.173 \\
\hline employed during studies & 0.402 & 0.301 & 1.340 & 0.181 & -0.187 & 0.991 \\
\hline university quality & -0.024 & 0.005 & -4.470 & 0.000 & -0.035 & -0.014 \\
\hline science-engineering & -0.353 & 0.365 & -0.970 & 0.335 & -1.069 & 0.364 \\
\hline social science & -0.011 & 0.317 & -0.030 & 0.973 & -0.632 & 0.610 \\
\hline non-stationary & 0.097 & 0.339 & 0.280 & 0.776 & -0.567 & 0.760 \\
\hline \multicolumn{7}{|l|}{ Wage aspirations } \\
\hline reservation wage & 0.000 & 0.000 & 1.910 & 0.056 & 0.000 & 0.000 \\
\hline constant & 12.730 & 38.508 & 0.330 & 0.741 & -62.744 & 88.205 \\
\hline \multicolumn{7}{|l|}{ Late migrants } \\
\hline \multicolumn{7}{|l|}{ Individual/family characteristics } \\
\hline sex & 0.002 & 0.344 & 0.010 & 0.995 & -0.673 & 0.677 \\
\hline married & 0.274 & 0.338 & 0.810 & 0.418 & -0.389 & 0.937 \\
\hline age & 6.183 & 3.482 & 1.780 & 0.076 & -0.642 & 13.008 \\
\hline age_square & -0.111 & 0.063 & -1.770 & 0.077 & -0.234 & 0.012 \\
\hline mother with university degree & 0.633 & 0.398 & 1.590 & 0.112 & -0.147 & 1.413 \\
\hline $\begin{array}{l}\text { mother with less than secondary } \\
\text { education }\end{array}$ & 0.440 & 0.412 & 1.070 & 0.286 & -0.368 & 1.248 \\
\hline more than 200 books at home & -0.091 & 0.440 & -0.210 & 0.837 & -0.953 & 0.771 \\
\hline graduated primary school in Warsaw & -1.626 & 1.145 & -1.420 & 0.156 & -3.872 & 0.619 \\
\hline father - high skilled white collar & -0.341 & 0.421 & -0.810 & 0.417 & -1.165 & 0.483 \\
\hline
\end{tabular}




\begin{tabular}{|c|c|c|c|c|c|c|}
\hline number of siblings & -0.082 & 0.171 & -0.480 & 0.634 & -0.417 & 0.254 \\
\hline birth order & -0.001 & 0.005 & -0.300 & 0.761 & -0.011 & 0.008 \\
\hline own room (primary) & 0.061 & 0.542 & 0.110 & 0.910 & -1.001 & 1.123 \\
\hline own room (secondary) & -0.382 & 0.620 & -0.620 & 0.538 & -1.596 & 0.833 \\
\hline \multicolumn{7}{|l|}{ Past migration experience } \\
\hline mother's migration & -0.057 & 0.427 & -0.130 & 0.893 & -0.893 & 0.779 \\
\hline $\begin{array}{l}\text { distance between primary and } \\
\text { secondary schools }\end{array}$ & 0.037 & 0.006 & 6.270 & 0.000 & 0.025 & 0.048 \\
\hline \multicolumn{7}{|c|}{ Hometown characteristics } \\
\hline population of municipality & 0.000 & 0.000 & -1.220 & 0.223 & 0.000 & 0.000 \\
\hline unemployment & 0.049 & 0.040 & 1.210 & 0.226 & -0.030 & 0.128 \\
\hline \multicolumn{7}{|c|}{ Secondary school characteristics/achievements } \\
\hline general secondary school & 0.022 & 0.415 & 0.050 & 0.957 & -0.791 & 0.836 \\
\hline maturity score (math-science) & -0.044 & 0.037 & -1.190 & 0.236 & -0.116 & 0.029 \\
\hline maturity score (humanistic) & 0.063 & 0.050 & 1.250 & 0.210 & -0.035 & 0.161 \\
\hline exempted from maturity exam & 0.510 & 0.517 & 0.990 & 0.323 & -0.502 & 1.523 \\
\hline \multicolumn{7}{|c|}{ Tertiary school characteristics/achievements } \\
\hline non-public tertiary & 0.288 & 0.454 & 0.640 & 0.525 & -0.601 & 1.177 \\
\hline graduated MA & 0.723 & 0.372 & 1.940 & 0.052 & -0.006 & 1.451 \\
\hline employed during studies & 0.570 & 0.350 & 1.630 & 0.103 & -0.116 & 1.256 \\
\hline university quality & -0.010 & 0.007 & -1.480 & 0.140 & -0.022 & 0.003 \\
\hline science-engineering & 0.772 & 0.383 & 2.020 & 0.044 & 0.022 & 1.522 \\
\hline social science & -0.217 & 0.410 & -0.530 & 0.597 & -1.021 & 0.587 \\
\hline non-stationary & 0.594 & 0.400 & 1.490 & 0.137 & -0.189 & 1.378 \\
\hline \multicolumn{7}{|l|}{ Wage aspirations } \\
\hline reservation wage & 0.000 & 0.000 & 0.310 & 0.759 & 0.000 & 0.000 \\
\hline constant & -90.441 & 48.144 & -1.880 & 0.060 & -184.802 & 3.920 \\
\hline
\end{tabular}

Source: own elaboration. 